\title{
MEDIATING SHARI'A AND RELIGIOUS FREEDOM: THE CASE OF THE SO-CALLED FALSE PROPHET IN INDONESIA ${ }^{1}$
}

\author{
Afifur Rochman Sya'rani \\ Center for Religious and Cross-Cultural Studies \\ Gadjah Mada University, Yogyakarta \\ afifurrochmans@gmail.com
}

\begin{abstract}
Indonesia's religious blasphemy law has been used to restrict the religious freedom of the so-called false prophet (nabi palsu). The prominent examples are Lia Eden and Ahmad Musadeq, to name but a few. They were previously Muslim and later maintain their prophethood respectively, claiming to be the heir of preceding prophets, most notably within the Abrahamic religions. Referring to this law, both Eden and Musadeq are arrested for the charge of blasphemy against religion. This article seeks to examine the phenomenon of Indonesian prophets from the perspective of Shari'a and human rights to religious freedom in the Indonesian context. Can both Shari'a and the Human Rights accommodate the Indonesian prophethood? This article aims at reconciling the two different viewpoints in favor of the realization of justice and equality regardless of religious identity. The reconciliation I propose implies evaluating permissible restrictions of religious freedom within the Indonesian legal framework that takes religious values into consideration.
\end{abstract}

\footnotetext{
1 This paper was originally presented at the $14^{\text {th }}$ CILIS Islamic Studies Postgraduate Conference, Center for Indonesian Law, Islam, and Society, Melbourne Law School, the University of Melbourne, 13-14 November 2018.
} 
[Hukum penodaan/penistaan agama di Indonesia digunakan untuk membatasi kebebasan beragama orang yang mengklaim sebagai nabi di Indonesia, misalnya figur seperti Lia Eden dan Ahmad Musadeq, untuk menyebutkan beberapa. Mereka sebelumnya adalah seorang Muslim dan kemudian mengklaim diri mereka sebagai nabi, pewaris para nabi sebelumnya, terutama dalam agama-agama Abrahamik. Berdasarkan hukum tersebut, Eden dan Musadeq ditangkap karena dituduh telah melakukan penistaan terhadap agama. Artikel ini berupaya untuk mengkaji fenomena para nabi Indonesia dari perspektif syariah dan hak asasi manusia tentang kebebasan beragama dalam konteks Indonesia. Bisakah Syariah dan Hak Asasi Manusia (HAM) mengakomodasi klaim kenabian di Indonesia? Artikel ini bertujuan untuk merekonsiliasi dua sudut pandang yang berbeda dalam upaya mendukung perwujudan keadilan dan kesetaraan tanpa memandang identitas agama. Rekonsiliasi yang saya usulkan berimplikasi pada evaluasi pembatasan kebebasan beragama yang diizinkan dalam kerangka hukum Indonesia yang mempertimbangkan nilai-nilai agama].

Keywords: human rights, religious freedom, religious blasphemy, shari'a, and new prophethood

\section{Introduction}

Religious freedom has been the most contested issue of human rights in Indonesia since the Reformasi partly due to democratization and decentralization. ${ }^{2}$ Although the 1945 constitution establishes a set of provisions to protect religious freedom, the phenomenon of the so-called "false prophet" (nabi palsu) features how religious freedom is highly debated in Indonesia. The prominent examples are Lia Eden and Ahmad Musadeq, to name but a few. They were previously Muslim and later maintain their prophethood respectively, claiming to be the heir of preceding prophets, most notably within the Abrahamic religions. However,

\footnotetext{
2 Zainal Abidin Bagir, "The Politics and Law of Religious Governance" in Robert W. Hefner (ed.), Routledge Handbook of Contemporary Indonesia (New York: Routledge, 2018), 284.
} 
they have been accused of the false prophet (nabi palsu). As such, they and their followers are persecuted and discriminated based on a religious judgment that they are deviant or heretic (sesat). More importantly, Indonesia's religious blasphemy law established in Article 156(A) of the Criminal Code and the 1965 presidential decision (UU No.1/PNPS/1965) remains used to criminalize the Indonesian prophets. Referring to this law, both Eden and Musadeq, for example, are arrested for the charge of blasphemy against religion. ${ }^{3}$

Arguably, such discrimination against the Indonesian prophets remains a violation of their religious freedom, as this contravenes the international human rights on freedom of religion or belief which cannot be diminished under any circumstances whatsoever. For Indonesian Muslims, therefore, Shari'a or theological perspective is insufficient in dealing with the Indonesian prophets. Rather, they also have to consider the international human rights into consideration as "a common moral standard", since Indonesia has ratified the International Covenant on Civil and Political Rights (ICCPR) in which its whole instruments must be implemented by the state.

This article seeks to discuss the phenomenon of Indonesian prophets in the light of Shari'a and the human rights on freedom of religion or belief in the Indonesian context. Can both Shari'a and human rights accommodate the Indonesian prophethood? I expect to contribute to the reconciliation of the two different points of view. This reconciliation is imperative for the realization of justice, equality, and tolerance, for all people regardless of their religious identity. According to Amin Abdullah, the perspective of human rights should be integrated with the principle of Islamic jurisprudence (ușül al-fiqh), for it significantly assists Muslims to deal with and respond to contemporary issues, particularly on religious

\footnotetext{
${ }^{3}$ Zainal Abidin Bagir, Kerukunan dan Penodaan Agama: Alternatif Penanganan Masalah (Yogyakarta: Center for Religious and Cross-Cultural Studies, Gadjah Mada University, 2017), 5-6.
} 
freedom. ${ }^{4}$ Abdullahi Ahmed An-Na'im also contends that reconciling the tension between religion and human rights is imperative as an attempt for cross-cultural dialogue for the sake of promoting "overlapping consensus around human rights values among different cultural and religious traditions". An-Na'im believes that through this mechanism, the agreement on human rights values can be reached across the different cultural and religious framework. ${ }^{5}$

\section{The Prophethood as Hierophany}

From a socio-historical point of view, the Prophet Muhammad is not the last prophet. This is due to the fact that he was not alone in claiming prophethood and founding religious communities during the seventh century of the Arabian Peninsula onwards. Rather, there remained other figures from various Arabian tribes although their religion failed to survive. In the Indonesian context, there have been a number of Indonesia-born figures who claim prophethood and founded religious communities alike even since the colonial period. After the 1998 Reformasi, among the prominent figures are Lia Eden, the founder of the Kingdom of Eden or Salamullah, and Ahmad Musadeq, the founder of Gafatar/Millah Abraham/Al-Qiyadah Al-Islamiyah. Some scholars identify these prophets as New Religious Movements (NRMs). ${ }^{6}$

According to $\mathrm{Al}$ Makin, the Indonesian prophets share a similar religious journey, i.e. they claim to undergo a divine revelation and receive divine messages which maintain their

\footnotetext{
${ }^{4}$ M. Amin Abdullah, "Hak Kebebasan Beragama dan Berkeyakinan: Pendekatan Filsafat Sistem dalam Ushul Fiqh Sosial", in Syamsul Arifin, Hasnan Bachtiar, and Umiarso (eds.), Hake Asasi Manusia untuk Kebebasan Beragama dan Berkeyakinan di Indonesia (Malang: PUSAM, 2015), 98-99.

5 Abdullahi Ahmed An-Na'im, "Human Rights and the Imperative of CrossCultural Dialogue: An Islamic Perspective", in Berma Klein Goldewijk (ed.), Religion, International Relations and Development Cooperation (Wageningen: Wageningen Academic Publisher, 2007), 308.

${ }^{6} \mathrm{Al}$ Makin, Challenging Islamic Orthodoxy: Accounts of Lia Eden and Other Prophets in Indonesia (Springer, 2016), 2-3.
} 
respective prophethood. In short, they claim that God has chosen them to be His prophets. Also, they are contextual, embedded in certain social, political, and cultural contexts in which they emerge respectively. These different contexts generate how they deal with and respond to their respective contemporary challenges and problems. $^{7}$

However, it is unfortunate that the Indonesian prophets are discriminated against and persecuted, based on a religious judgment that they are heterodox or heretic. Indeed, such a judgment does not represent their voice. Rather, they are judged from the lens of the Islamic orthodoxy that the door of prophethood is sealed after God sent the Prophet Muhammad to the earth. The Indonesia Council of Ulema (MUI) plays a leading role in making such a judgment through issuing a fatwa (Islamic legal opinion). Since they are judged on the basis of Islamic orthodoxy, there will be no sharedunderstanding that supports religious freedom, tolerance, and peaceful co-existence.

In this regard, I would argue that the phenomenon of the Indonesian prophets can be understood as a form of bierophany, Mircea Eliade's theory of the manifestation of the sacred. By proposing this, I expect that one would be more empathetic to deal with the phenomenon. Eliade argues that the nature of religion should be understood in the light of its unique element, namely the sacred. He used the term hierophany to acknowledge that people of faith believe in the sacred because "it manifests itself and shows itself as something wholly different from the profane." ${ }^{\prime \prime}$ This means that the sacred is neither the product of social construction nor that of human association. Rather, it goes beyond human intellect and experience. For Eliade, the main problem is not whether the sacred is irrational or not, but rather how it is understood and believed by religious adherents.

\footnotetext{
${ }^{7}$ Ibid, $2-5$.

${ }^{8}$ Mircea Eliade, The Sacred and The Profane: The Nature of Religion (New York: A Harvest Book, 1957), 11.
} 
Prophethood, as the sacred, represents hierophany. How do prophets believe that they are chosen by God? In the Abrahamic religions, they share a similar divine experience: revelation. God speaks to them directly or indirectly to convince them that they are chosen by Him. No one understands the ontological reality of divine revelation, except the prophets themselves. "That manifests its self and shows itself as something wholly different" from our experience as a human being. Divine revelation, thus, is hierophany. People of faith only believe in it and cannot rationalize it.

More clearly, let us take the example of Moses. He saw that the angel manifested in the flame which did not burn the bush. Then he heard a mysterious voice. "Draw not nigh hither," says the Lord to Moses; "put off thy shoes from off thy feet, for the place whereon thou stand is holy ground" (Exodus, 3, 5). From these verses, we can see the manifestation of the divine in the form of miraculous flame and mysterious voice, both of which are beyond human experience.

Divine revelation as bierophany was also experienced by the Prophet Muhammad. When he retreated and contemplated in the cave of Hira, the archangel Gabriel came to him to reveal the Qur'an. This divine experience was never experienced by the Prophet Muhammad before. It is also said that the way in which the Qur'an was revealed to him sometimes resembles the ringing of a bell. No one understands the reality of the archangel Gabriel and how the Qur'an was revealed, except the Prophet Muhammad himself.

Similar to the Abrahamic prophets, the Indonesian prophets also experience a divine revelation. Lia Eden, for example, experienced her first bierophany in 1995 when a supernatural being called Habib al-Huda came to her. She also frequently heard "the unseen voices" that guided her spiritually. In 1974, she told that she saw a ball with yellow light than flown to her head and then faded away on a floor. In 1997, Lia confessed that the mysterious supernatural being, Habib al-Huda, was the archangel Gabriel who 
brought the message of God for her. In short, Lia was convinced that she was chosen to be the prophet of God.'

What can we conclude from the hierophany of the Prophet Moses, Muhammad, and Lia Eden? First, they have a common hierophany, namely divine revelation. Second, only those who experience it can understand its ontological reality, because it is wholly different from human intellect, experience, and feeling. Third, divine revelation as hierophany is not a matter of rationality, but faith.

\section{Religious Freedom, Blasphemy Law, and Prophethood in Indonesia}

In essential, Indonesian has a set of provisions for guaranteeing and protecting freedom of religion or belief. This can be seen in the 1945 Constitution, particularly after its amendment in 1999 which introduces rights to religious freedom adopted from UDHR and ICCPR. There are two articles of the Constitution constitutes the protection of freedom of religion or belief. First, Article 29 states:

The State guarantees all persons the freedom to embrace their religion (memeluk agamanya) and to worship (beribadat) in accordance with their religion and beliefs (kepercayaan).

Second, Article 28E states:

1. Each person is free to embrace their religion (memeluk agamanya) and to worship (beribadat) in accordance with their religion...

2. Each person has the freedom to possess beliefs (kepercayaan) and to express their thoughts and attitudes following their conscience.

Article 28I states:

${ }_{9}^{\mathrm{Al}}$ Makin, Challenging Islamic Orthodoxy, 32-33. 
The right to life, the right to not be tortured, the right to freedom of thought and conscience, the right to have a religion (hak beragama), the right to not be enslaved, the right to be recognized as an individual before the law, and the right to not be prosecuted under a law of retrospective application are human rights that cannot be limited under any circumstances.

It is noteworthy that while both Article 29 and 28I only acknowledge freedom to "embrace religion" or "having religion", which constitutes forum internum, Article $28 \mathrm{E}$ acknowledges both that freedom and freedom to manifest religion, which constitutes forum externum. Also, unlike the other two articles, Article 28I peculiarly states that "right to have a religion" is non-derogable right, i.e. "it cannot be limited under any circumstances". Nonetheless, it seems inconsistent that in a number of cases, the Constitutional Court argues that all of these articles are subject to limitation due to Article 28J(2) of the Constitution: ${ }^{10}$

In carrying out his/her rights and freedom, every citizen has the responsibility to abide by the restrictions set out by legislation protecting the rights and freedoms of others and which accords with moral considerations, religious values, security and public order in a democratic society.

Accordingly, Article 28J(2) allows the state to limit individual religious freedom, as applied in the Blasphemy Law. In a number of cases considered as defamation against religion, the Court frequently uses the rhetoric of "religious values" and "maintaining public order" (kerukunan) to limit religious freedom of religious minority groups deemed as deviant (sesat) and even criminalize them, such as in the case of Lia Eden and Ahmad Musadeq, the Indonesian

\footnotetext{
10 Tim Lindsey and Simon Butt, "State Power to Restrict Religious Freedom: An Overview of the Legal Framework", in Tim Lindsey and Helen Pausacker (eds.), Religion, Law and Intolerance in Indonesia (New York: Routledge, 2016), 22-23.
} 
prophets, Ahmadiyah, and Shiite community. ${ }^{11}$ As a matter of fact, the 1965 presidential decision (UU No.1/PNPS/1965) only acknowledges the six official religions (Islam, Catholicism, Protestantism, Hinduism, Buddhism, and Confucianism). It is noteworthy that it also distinguishes between religions and beliefs (kepercayaan). ${ }^{12}$

The Blasphemy Law has been highly criticized and brought to the Constitutional Court for judicial review, albeit always fails. For instance, what counts as religious values as a consideration to limit religious freedom is highly contested. Arguably, it is likely vague, since religion is subject to various interpretations. Accordingly, a religious value might vary depending on a particular religious interpretation. This is peculiarly unique in the 1945 Constitution since international human rights do not include such a consideration. In this regard, scholars and activists criticize the Blasphemy Law, as the state uses its power to determine what constitutes blasphemous in an authoritarian way. In the case of the Indonesian prophets, the state frequently refers to the orthodox Sunni Islam represented by MUI through its fatwa (Islamic legal opinion)_often with mass mobilization-to determine that they are deviant and blasphemous. ${ }^{13}$ Therefore, the consideration of religious values is not neutral, but it is based on majoritarianism.

\section{Prophethood from the Perspective of Human Rights}

The human rights establish a set of provisions for the protection of freedom of religion or belief (FORB), along with other human rights, as contained within Article 18 of both the Universal Declaration of Human Rights (UDHR) and the International Covenant on Civil and Political Rights (ICCPR). Article 18 of UDHR constitutes a general explanation of the right to FORB:

\footnotetext{
${ }^{11}$ Ibid, 23-25; Bagir, "The Politics and Law of Religious Governance", 289.

12 Ibid, 24.

13 Ibid, 24-25. Bagir, "The Politics and Law of Religious Governance", 289; Bagir, Kerukunan dan Penodaan Agama: Alternatif Penanganan Masalah, 8-9.
} 
"Everyone has the right to freedom of thought, conscience, and religion; this right includes freedom to change his religion or belief, and freedom, either alone or in community with others and in public or private, to manifest his religion or belief in teaching, practice, worship, and observance". ${ }^{14}$

Meanwhile, Article 18 of ICCPR maintains that:

1. Everyone shall have the right to freedom of thought, conscience, and religion. This right shall include freedom to have or to adopt a religion or belief of his choice, and freedom, either individually or in community with others and in public or private, to manifest his religion or belief in worship, observance, practice, and teaching.

2. No one shall be subject to coercion which would impair his freedom to have or to adopt a religion or belief of his choice.

3. Freedom to manifest one's religion or beliefs may be subject only to such limitations as are prescribed by law and are necessary to protect public safety, order, health, or morals or the fundamental rights and freedoms of others. ${ }^{15}$

Accordingly, at least there are three significant points of the human rights to FORB. First, FORB is a fundamental right which cannot be derogated from any circumstances whatsoever. It is applied universally to each human being just because of their inherent status as human beings regardless of their religion, ethnicity, race, nationality, etc. This principle is named as forum internum which is not subject to derogation. Second, FORB also guarantees rights to manifest religion, including rights worship,

\footnotetext{
14 United Nations, Universal Declaration of Human Rights, illustrated edition, 2015, 38.

${ }^{15}$ United Nations, International Covenant on Civil and Political Rights, Treaty Series, 1976, 178.
} 
observance, practice and teaching, and even conversion. This principle is named as forum externum which is subject to derogation, i.e. it is not absolute freedom, but rather can be limited under certain circumstances. Third, the limitation of forum externum is justifiable if it is "prescribed by law and are necessary to protect public safety, order, health, or morals or the fundamental rights and freedoms of others" - as established in Article 18 of ICCPR. ${ }^{16}$

According to Heiner Bielefeldt, from the perspective of human rights, religious freedom constitutes part of human nature. Therefore, it should be respected as "a manifestation of the potential of human responsibility and hence something intrinsically positive". Bielefeldt contends that each individual has the inherent ability to figure out his/her faith or belief. As such, respecting religious freedom also constitutes the recognition of human dignity as established in the preamble opening of UDHR. Bielefeldt further insists that religious freedom is "a universal right which all human beings have a claim to just because of their inherent dignity as members of the human family". 17

It is noteworthy that by looking at the General Comment No. 22 of Article 18 of ICCPR, the right to freedom of religion or belief constitutes a broad scope. It insists that the term religion and belief include theistic, non-theistic, and atheistic beliefs, indigenous religions, traditional beliefs, religious minority groups, newly established religions, and even rights to not profess any religion or belief. ${ }^{18}$ Given this broad understanding, it is clear that prophethood claims after the Prophet Muhammad are included under freedom of religion or belief, which must be respected and protected. Yet, the problem arises concerning their manifestation of religion-forum

\footnotetext{
${ }^{16}$ Natan Lerner, "The Nature and Minimum Standards of Freedom of Religion or Belief", in Tore Lindholm, et. al (ed.), Freedom of Religion or Belief: A Desk Book, (Oslo: the Oslo Coalition on Freedom of Religion or Belief, 2004), 67-68.

${ }^{17}$ Heiner Bielefeldt, "Freedom of Religion or Belief: A Human Rights under Pressure", Oxford Journal of Law and Religion, 2012, 2-6.

${ }^{18}$ Ibid, 6.
} 
externum — which requires scrutiny, as the limitations are likely made in favor of majority demands. ${ }^{19}$

\section{The Finality of Muhammad's Prophethood and Apostasy}

Testifying Muhammad's prophethood is one of the ultimate doctrines in Islamic theology. While Muslims must testify that there is no God but Allah, they must also testify that the Prophet Muhammad is His prophet and messenger. This theological doctrine is called shabädah, one of the five pillars of Islam, to which each Muslim must declare as a requirement to embrace Islam. More importantly, this Islamic doctrine also affirms that Muhammad is the final prophet. In other words, the door of prophethood is sealed after him. Therefore, testifying Muhammad's prophethood also implies testifying his final prophethood.

Muslim exegetes base the doctrine of finality of Muhammad's prophethood on Q. 33: 40: "Muhammad is not the father of any of your man, but (he is) the Messenger of Allah and the Seal of the Prophet: and Allah has full knowledge of all things". In commenting on the phrase "the seal of the Prophet (khatam alnabiyyin), al-Ṭabari states that the phrase acknowledges Muhammad as the Last Prophet. ${ }^{20}$ Ibn Kathīr contends that the phrase emphasizes that "there will be no prophet after him". ${ }^{21}$ The finality of Muhammad's prophethood is also upheld by other Muslim exegetes, such as al-Rāzi, al-Qurțubi, and al-Zamakhshari. ${ }^{22}$

\footnotetext{
19 See Manfred Nowak and Tanja Vospernik, "Permissible Restrictions on Freedom of Religion or Belief", in Tore Lindholm, et. al (ed.), Freedom of Religion or Belief: A Desk Book (Oslo: the Oslo Coalition on Freedom of Religion or Belief, 2004), 147.

20 Ibn Jarīr al-Ṭabarī, Jāmi' al-Bayān 'an Ta'wūl Āy al-Qur'àn (Cairo: Markāz alBuḥūth wa al-Dirasāt al-'Arabiyyah wa al-Islāmiyyah, 2001), vol. 19, 121-123.

${ }^{21}$ Ibn Kathīr, Tafsìr al-Qur'ān al-'Aẓim (Giza: Maktabah Aulād al-Syaīkh li alTurāth, 2000), vol. 11, 175-176.

22 See Fakhruddīn al-Rāzi, Mafätīh al-Ghaib (Beirut: Dar al-Fikr, 1981), vol. 15, 125; 'Abdullah Muhammad bin Ahmad Abī Bakr al-Qurțubī, al-Jāmi' li al-Ahkēm alQur'àn (Muassat al-Risalah), vol. 19, 165-166; Mahmūd bin 'Umar alZamakhshari, al-Kashshäf (Riyadh: Maktabah al-'Abikkan, 1998), vol. 5, 75-76.
} 
The finality of Muhammad's prophethood is also affirmed by Hadith, the Prophetic tradition. Ibn Kathīr cited several Hadiths on the finality of Muhammad's prophethood narrated by Ibn Hanbal. A Hadith depicts the finality of Muhammad's prophethood as a brick that completes a building. It is said that Muhammad is "the seal of prophethood". In another Hadith, the Prophet Muhammad says that "the message and prophethood were cut off, so there will be no messenger and prophet after me". ${ }^{23}$

Given the finality of Muhammad's prophethood, it is clear that there is no place for the Indonesian prophets in Islamic theology. Accordingly, from the perspective of Islamic jurisprudence, believing in and claiming a person's prophethood after the Prophet Muhammad constitutes a form of apostasy.

In Islamic jurisprudence, the legal definition of apostasy (riddah) is "turning away from Islam" or "severing the ties with Islam". Therefore, an apostate is "a Muslim who by conversion renounces Islam and embrace to another faith". A Muslim will be judged as an apostate if he/she utters an apostasy utterance either explicitly or implicitly. Although there remains no definite standard of what constitutes admissible apostasy utterances, Muslim jurists provide a myriad of indications constituting apostasy. ${ }^{24}$

A Hanafite scholar, Shakhzādeh provides an extensive classification for indications of apostasy. I only point out the classification pertaining to prophethood due to its relevance to the purpose of this article. Examples of this classification include to abjure Muhammad's prophethood; to insist that prophets are free of error; "to consider oneself a Prophet", to insist that all animals have their particular prophet. ${ }^{25}$ Accordingly, the phrase to consider oneself a Prophet implies that a Muslim who claims his/her prophethood, testifies a person's prophethood, and believes in the

\footnotetext{
${ }^{23}$ See Ibn Kathīr, Tafsìr al-Qur'ān al-'Azim, 176-179

${ }^{24}$ Rudolph Peters and Gert J.J De Vries, “Apostasy in Islam”, Die Welt des Islams, $17(1-4), 1977,2-3$.

${ }^{25}$ Ibid, 3-4.
} 
coming of a prophet after the Prophet Muhammad is legally judged as an apostate.

Most all schools of Islamic jurisprudence agree that the punishment for an apostate is a death penalty. Also, they, except the Hanafite, agree that an apostate must be obligatory exhorted to repent and re-embrace Islam during certain periods. However, there remains debate among Shafiite and Hanafite school over the restriction of whether an apostate will get the death penalty or not. Besides, apostates are subject to the civic laws, i.e. their rights to dispose of property are in abeyance (mawqüf) and their rights to inherit property are not valid. As a consequence, their estate will be distributed to the public treasury (bayt al-mā') and considered as fay' ("enemy property returning to Islamic treasury without warfare"). ${ }^{26}$

Muslim jurists base the apostasy law on several Hadiths explaining the death penalty for an apostate. For example, a Hadith narrated by Ikrimah from his master, Ibn 'Abbās, says that "whosoever changes his religion, kill him". Another version of the Hadith, reported by al-Bukhāri and al-Nasāài, says:

\begin{abstract}
"It is not lawful to shed the blood of a Muslim person who testifies that there is no God but Allah and that I am the messenger of Allah, except in three cases: a married person guilty of adultery, or life for a life, or a person who abandoned his faith and deserted the community". ${ }^{27}$
\end{abstract}

\title{
Towards a Reconciliation
}

From the preceding discussions, we can see that in the case of the Indonesian prophets, there remains a contradiction between freedom of religion or belief and Shari'a. The former protects and respects the prophethood claim after the Prophet Muhammad as a manifestation of religious freedom. The latter, by contrast, views

\footnotetext{
${ }^{26}$ Ibid, 5-9.

27 See Samuel Hosain Lamarti, The Development of Apostasy and Punishment Law in Islam $11 A H / 632 A D-157 A H / 774 A D$, Ph. D Dissertation, Faculty of Divinity, Glasgow University, Scotland, UK, 2002, 111-118.
} 
that as a form of apostasy due to the doctrine of the finality of Muhammad's prophethood. In this regard, is it possible to mediate the two conflicting views?

In my point of view, it is highly impossible to reinterpret the doctrine of the finality of Muhammad's prophethood, because it is one of the ultimate doctrines in Islamic theology. Nonetheless, there remains a possible attempt for reconciliation to accommodate the Indonesian prophets' religious freedom. I would argue that such an attempt is possible by reforming the concept of apostasy in Islamic jurisprudence, on the one hand, and emphasizing the principle of religious freedom in the Qur'an, on the other hand. In doing so, I will refer to the progressive Muslim scholars' approach, particularly Jasser Auda's thought on maqāșid al-shari'a, considering its relevance to contemporary Muslims' context. According to Auda, maqāșid alshari'a is "today's most important intellectual means and methodologies for Islamic reform". ${ }^{28}$ Mohammed Talbi, a Tunisian Muslim thinker, also argues that it is the basic idea and spirit of the Qur'an and thus understanding maquașid al-shari'a of a particular Qur'anic verse is significant for Islamic contextualization. ${ }^{29}$

Maqāsid al-shari'a by definition is the purpose or objectives underlying Islamic law or rulings. ${ }^{30}$ According to Mohammad Abed al-Jabiri, Shari'a consists of three elements: general fundamentals (kulliyata), particular rulings (juriyyatt), principles and application. Therefore, according to al-Jabiri, there are three main features required to understand "the rationality of Shari'a rulings in Islam", namely "general fundamentals of Shari'a, particular rulings, the intents of Shari'a, and the occasion of revelation".31 More comprehensively, Jasser Auda developed and reconstructed the traditional theory of maquasid in light of the system approach. His

\footnotetext{
${ }^{28}$ Jasser Auda, Maqasid Al-Shariah as Philosophy of Islamic Law: A Systems Approach (London: The International Institute of Islamic Thought, 2007), 8-9.

${ }^{29}$ Mohammed Talbi, Ummat al-Wasaț (Tunisia: Sarar li al-Nasyr, 1996), 118.

${ }^{30}$ Jasser Auda, Maqasid Al-Shariah..., 2.

31 Mohammad Abed Al-Jabiri, Democracy, Human Rights and Law in Islamic Thought (London: I.B. Tauris, 2009), 196.
} 
theory comprises five features: cognitive nature, wholeness, openness, multi-dimensionality, purposefulness. All these features will be discussed below and employed in favor of the reconciliation.

First, in terms of Islamic law, the cognitive feature allows us to distinctly distinguish between divine revelation and human reason. In this regard, Islamic jurisprudence (figh) has to be considered as merely Muslim jurists' construction and conceptualization to understand the revealed texts (the Qur'an and Hadith) rather than God's rulings. As a consequence, Islamic rulings contained in figh are not absolute, but rather temporary. They are embedded in a variety of particular contexts in which various Muslim jurists live. ${ }^{32}$ Accordingly, the concept of apostasy in Islamic law is highly possible to be reinterpreted in light of the contemporary context.

Second, the wholeness feature requires the holistic approach in making a particular ruling, by which all the whole Islamic texts on a particular issue should be taken into account. This is different from the atomistic or reductionist approach which only refers to particular Islamic texts and neglects the others in making a particular ruling. ${ }^{33}$ Therefore, concerning apostasy law, one should also take Qur'anic verses on religious freedom, on the one hand, and apostasy, on the other hand, into account, not only based on the Hadith.

Third, the openness feature presupposes that Islamic law should establish "a degree of openness and self-renewal" to respond to contemporary challenges. According to Auda, the openness of Islamic law manifests in how Muslim jurists' worldview is likely to change and evolve, and this implies that Islamic rulings are subject to change. In nature, a person's worldview is embedded in a particular socio-historical, political, and geographical context. Meanwhile, Muslims' contemporary context is different from the context of the seventh century Arabia peninsula in which the

\footnotetext{
32 Jasser Auda, Maqasid Al-Sharia, 193-195.

33 Ibid, 197.
} 
Prophet lived. Accordingly, the change of context implies the change of worldview. ${ }^{34}$ In this vein, I would argue that concerning the apostasy law, Muslims should also take the human rights on freedom of religion or belief into consideration as part of their contemporary worldview. This is because some Muslim-majority countries, most notably Indonesia, have ratified UDHR and its legally binding instruments such as ICCPR and ICESCR.

Fourth, the multi-dimensionality feature is the continuance of the wholeness feature. While the holistic approach takes the whole Islamic texts on a particular issue in making a particular ruling, the multi-dimensionality approach aims at examining those to determine the "spectrum of certainty (qat' 'yy)" and to overcome contradiction among them. ${ }^{35}$ In this regard, I would provide and examine the whole Islamic texts in relation to apostasy, namely Qur'anic verses on religious freedom and apostasy, the prophetic tradition (Hadith) on apostasy, and the history of Musaylima, the false prophet during the Prophet Muhammad's lifetime, and the apostasy war undertaken by Abū Bakar, the first Caliph.

Arguably, The Qur'an calls for religious freedom as established in the following verses: "Let there be no compulsion in religion: Truth stands out clear from Error" (al-Baqarah [2]: 256); "If it had been thy Lord's will, they would all have believed,- all who are on earth! Wilt thou then compel mankind, against their will, to believe!" (Yunus [10]: 99); “The truth is from your Lord: let him who will believe, and let him will reject (it)" (al-Kahfi [18]: 29); "We showed him the Way: whether he be grateful or ungrateful (rests on his will)" (al-Insān [76]: 3); “Therefore do thou give admonition, for thou art one to admonish, thou art not one to manage affairs" (alGhashiyah [88]: 21-22); "If they then turn away thee as a guard over them, thy duty is but to convey the message (Shura [42]: 48)". ${ }^{36}$

\footnotetext{
34 Ibid, 201-206.

35 Ibid, 211-226.

${ }^{36}$ All of the Qur'anic verses translations are taken primarily from Abdullah Yusuf 'Ali, The Meaning of the Holy Qur'an (Bandung: Mizan, 2007).
} 
According to al-Jabiri, based on those verses, it is likely to clear that the Qur'an provides a set of provisions for religious freedom. Everyone is free to embrace Islam and if he/she turns away, the Messenger has no obligation to compel him/her to follow Islam. ${ }^{37}$

Nonetheless, the Qur'an also explains about apostasy. The following Qur'anic verses acknowledge the status of an apostate and its punishment: "and if any of you Turn back from their faith and die in unbelief, their works will bear no fruit in this life and in the Hereafter; they will be companions of the Fire and will abide therein" (al-Baqarah [2]: 217); "How shall Allah Guide those who reject Faith after they accepted it and bore witness that the Messenger was true and that Clear Signs had come unto them? But Allah guides not a people unjust. Of such the reward is that on them [rests] the curse of Allah, of His angels, and of all mankind" (alImrān [3]: 86-87); "If anyone contends with the Messenger even after guidance has been plainly conveyed to him, and follows a path other than that becoming to men of Faith, We shall leave him in the path he has chosen, and land him in Hell,- what an evil refuge!" (alNisā' [4]: 115); Anyone who, after accepting faith in Allah, utters Unbelief,- except under compulsion, his heart remaining firm in Faith - but such as open their breast to Unbelief, on them is Wrath from Allah, and theirs will be a dreadful Penalty" (al-Nahl [16]: 106).

Based on those verses, it is noteworthy that although the Qur'an views apostasy as bad behavior, the punishment for an apostate is absolutely given by God at the hereafter, not by humans. This, therefore, contravenes the punishment for apostasy in Islamic jurisprudence, namely the death penalty. As explained before, Muslim jurists refer to the Hadith in making the rulings for apostasy. It is also supported by the history of Musaylima and apostasy war during Abū Bakar's period.

Then the question is how to reconcile such a contradiction? To overcome the contradiction among Islamic rulings, one should

\footnotetext{
${ }^{37}$ Mohammad Abed Al-Jabiri, Democracy, Human Rights and Law in Islamic Thought, 197-198.
} 
distinguish which one includes the general principle (kulliyatt) and particular rulings (juz'iyyät) of Shari'a. Also, one should examine the underlying sources of particular rulings in their respective contexts. ${ }^{38}$ More importantly, the maqașid approach or the feature of purposefulness-referring to Auda's term—should be taken into account. $^{39}$

Accordingly, the Qur'anic worldview on religious freedom should be positioned as a universal principle that is unchangeable (kully). ${ }^{40}$ This is due to and derived from the aforementioned numerous Qur'anic verses establishing this principle. Therefore, God's punishment for apostasy in the hereafter should be considered as a form of religious freedom, because it does not take a human intervention. Meanwhile, the death penalty for an apostate is a particular ruling (juz'iy). In this regard, Al-Jabiri argues that "religious freedom is one thing and apostasy is another" which requires a critical examination. ${ }^{41}$ At this point, I would examine the context of sources underlying apostasy law in Islamic jurisprudence: the Hadith, history of Musaylima, and apostasy war.

There are at least two Hadiths which acknowledge death penalty for an apostate: "whosoever changes his religion, kill him" and "it is not lawful to shed the blood of a Muslim person who testifies that there is no god but God and that I am the messenger of God, except in three cases: a married person guilty of adultery, or life for a life, or a person who abandoned his faith and deserted the community". However, these Hadiths remain problematic because of two reasons. First, they are isolated Hadith (ahad). Second, they are lack information on which circumstance they were uttered. Hence, this leads to the debate among Muslim jurists concerning the restriction of the death penalty. Some of them argue that a female

\footnotetext{
${ }^{38}$ Ibid, 198

${ }^{39}$ Jasser Auda, Maqasid Al-Shariah..., 224.

40 Abdullah Saeed and Hassan Saeed, Freedom of Religion, Apostasy, and Islam (New York: Routledge, 2004), 2.

${ }^{41}$ Mohammad Abed Al-Jabiri, Democracy, Human Rights and Law in Islamic Thought, 199.
} 
apostate is excluded from the death penalty, while some others argue that she is included. Some of them argue that the Hadiths encompass all religious believers, not only Muslims, while others argue that they are applied to Muslims only. ${ }^{42}$ Due to the problematical Hadiths, they do not have a certainty ( $q a t^{\prime}$ ' $y$ ), and thus cannot be applied directly, but rather require a critical examination.

Examining the history of Musaylima and apostasy war will assist us to understand the circumstance on how early Muslim generations dealt with apostasy. The appearance of a person who claims prophethood is not relatively modern. During the lives of the Prophet Muhammad, Musaylima, son of Habib from the tribe Hanifa in Yamāma, claimed his prophethood. Towards the end of the year 10 H/631-632 AD, Musaylima sent a letter to the Prophet Muhammad in Medina, declaring his prophethood claim. The Prophet Muhammad then answered his letter, saying that Musaylima was the arch liar. ${ }^{43}$ Muslim literature even recorded that both the Prophet Muhammad and Musaylima also had encountered. In the year 10H/631-632 AD, the Hanīfa tribe, settled in Yamāma, sent its delegation to the Prophet Muhammad in Medina. According to Al Makin, like other Arabian tribes, its intention to seek a political alliance with Medina. Interestingly, it is said that Musaylima also attended among the members of the delegation. ${ }^{44}$

It must be noted that the Prophet Muhammad only rejected Musaylima's prophethood claim, not declaring war against him. Subsequently, challenging Musaylima's prophethood was continued by later generation, particularly during Abū Bakar's period by waging war so-called apostasy war (hurūb al-riddab). However, the term apostasy war is highly debated among scholars. Some of them argue that the war against the apostates is not simply the so-called apostasy war, because many of the tribes did not apostatize from

\footnotetext{
${ }^{42}$ Lamarti, the Development of Apostasy and Punishment Law in Islam, 111-117.

${ }^{43} \mathrm{Al}$ Makin, Representing the Enemy, Musaylima in Muslim Literature, (Frankfurt: Peter Lang, 2008), 26-27.

${ }^{44}$ Ibid, 93-94.
} 
Islam. Although some of the tribes apostatized from Islam, they were mostly political movements against the authority of Medina after the death of the Prophet Muhammad, as they withheld the payment of qakat and sadaqah. ${ }^{45} \mathrm{Al}$ Makin concluded that "in the light of succession to tribal leadership, a political Musaylima was perceived as a threat to Medina from the time of the end of the Prophet's life to early years of Abū Bakar reign". ${ }^{46}$

Based on the above discussion, the history of apostasy in the early Muslim period is full of political nuance, not merely turning away from Islam. ${ }^{47}$ Therefore, the apostates arguably constitute those who betrayed and renounced the Islamic state and became conspirators of the enemy. ${ }^{48}$ In such socio-political milieu, the Hadiths on the death penalty for apostasy were probably narrated and employed to fight against them. Accordingly, we can understand that the maquasid (purposefulness) of the Hadiths is to avoid any threats threatening the sovereignty of the state. Besides, it is must be noted that the hadiths were constrained by their particular socio-historical and political context. ${ }^{49}$ Hence, they cannot be applied in our contemporary context. Rather, they require a contextual reading, namely by applying the maqūsid.

\section{Conclusion}

From the preceding discussions, we can conclude with the following remarks. Concerning new prophethood claims after the Prophet Muhammad, the human rights to freedom of religion or belief and Shari'a can be reconciled in favor of accommodating religious freedom of the Indonesian prophets and their followers. Both the human rights and Sharia establishes a set of provisions of

\footnotetext{
${ }^{45}$ Ibid, 233; Lamarti, the Development of Apostasy and Punishment Law in Islam..., 127 128.

46 Ibid, 143.

${ }^{47}$ Abdullah Saeed and Hassan Saeed, Freedom of Religion, Apostasy and Islam, 3.

${ }^{48}$ Mohammad Abed Al-Jabiri, Democracy, Human Rights and Law in Islamic Thought, 199.
} 
religious freedom for those who claim and believe in new prophethood, as well as to manifests their religiosity. However, the concept of apostasy in Islamic jurisprudence is subject to reinterpretation, for it can be used as a theological justification to discriminate and even persecute the so-called "deviant sects". As such, the Qur'anic worldview on religious freedom constitutes the universal principle which is unchangeable in terms of place and time. Therefore, Qur'anic worldview on apostasy should be considered as a manifestation of religious freedom, as it does not take human intervention to punish. As such, the death penalty for apostasy should be positioned as a particular ruling which is only relevant to the particular context of the early Muslim generation.

Indeed, from the perspective of Islamic theology, the Indonesian prophethood is deviant. But, given the reconciliation, any discriminations and persecutions cannot be justified. They have equal rights before the law and to free from discrimination and oppression. Muslims are allowed to claim the finality of Muhammad's prophethood, but it cannot hamper them to be tolerant toward those who do not believe such doctrine. Besides, the reconciliation that I propose implies on the permissible restrictions of religious freedom within the Indonesian legal framework, which consider religious values. In terms of statereligion relations, religious values are always contested. They are highly dependent on various interpretations. Accordingly, if Shari'a can accommodate the Indonesian prophet's religious freedom, then the state-actors should think that their religious freedom is not contrary to Islamic values. Therefore, they are neither blasphemous nor defamatory against Islam. Rather, they have different theology considered against Islam. They just remain the same in comparison to the other religious adherents who do not believe in the finality of Muhammad's prophethood. Yet, the challenge is how the state does not favor the majoritarian demands upholding the Islamic orthodoxy to restrict the religious freedom of the accused-deviant sects. 


\section{Bibliography}

'Ali, 'Abdullah Yusuf, The Meaning of the Holy Qur'an, Bandung: Mizan, 2007.

Abdullah, M. Amin, "Hak Kebebasan Beragama dan Berkeyakinan: Pendekatan Filsafat Sistem dalam Ushul Fiqh Sosial", in Syamsul Arifin, Hasnan Bachtiar and Umiarso (Eds.), Hak Asasi Manusia untuk Kebebasan Beragama dan Berkeyakinan di Indonesia, Malang: PUSAM, 2015.

Al Makin, Representing the Enemy, Musaylima in Muslim Literature, Frankfurt: Peter Lang, 2008.

----, Challenging Islamic Orthodoxy: Accounts of Lia Eden and Other Prophets in Indonesia, Springer, 2016.

Al-Jabiri, Mohammad Abed, Democracy, Human Rights and Law in Islamic Thought, London: I.B. Tauris, 2009.

Al-Qurțubī, 'Abdullah Muhammad, al-jāmi' li al-Abkeàm al-Qur'àn, Muassat al-Risalah.

Al-Rāzi, Fakhruddīn, Mafätīh al-Ghaib, Beirut: Dar al-Fikr, 1981.

Al-Ṭabarī, Ibn Jarīr, Jämi' al-Bayān 'an Ta'wīl Āy al-Qur'ān, Cairo: Markāz al-Buhūth wa al-Dirasāt al-'Arabiyyah wa alIslāmiyyah, 2001.

Al-Zamakhshari, Mahmūd bin 'Umar, al-Kashshäf, Riyadh: Maktabah al-'Abīkan, 1998.

An-Na'im, Abdullahi Ahmed, "Human Rights and the Imperative of Cross-Cultural Dialogue: An Islamic Perspective", in Berma Klein Goldewijk (Ed.), Religion, International Relations and Development Cooperation, Wageningen: Wageningen Academic Publisher, 2007.

Auda, Jasser, Maqasid Al-Shariah as Philosophy of Islamic Law: A Systems Approach, London: The International Institute of Islamic Thought, 2007.

Bagir, Zainal Abidin, "Kerukunan dan Penodaan Agama: Alternatif Penanganan Masalah”, Laporan Kehidupan Beragama di Indonesia, 
Center for Religious and Cross-Cultural Studies, Gadjah Mada University, 2nd edition, December, 2017.

----, "The Politics and Law of Religious Governance" in Robert W. Hefner (Ed.), Routledge Handbook of Contemporary Indonesia, New York: Routledge, 2018.

Bielefeldt, Heiner, "Freedom of Religion or Belief: A Human Rights under Pressure", Oxford Journal of Law and Religion, 2012.

Eliade, Mircea, The Sacred and The Profane: The Nature of Religion, (New York: A Harvest Book, 1957.

Kathīr, Ibn, Tafsìr al-Qur'ān al-'Ażìm, Giza: Maktabah Aulād alSyaīkh li al-Turāth, 2000.

Lamarti, Samuel Hosain, The Development of Apostasy and Punishment Law in Islam $11 A H / 632 A D-157 A H / 774 A D, \mathrm{Ph} . \mathrm{D}$

Dissertation, Faculty of Divinity, Glasgow University, Scotland, UK, 2002.

Lerner, Natan, "The Nature and Minimum Standards of Freedom of Religion or Belief', in Tore Lindholm, et. al (Eds.), Freedom of Religion or Belief: A Desk Book, Oslo: the Oslo Coalition on Freedom of Religion or Belief, 2004.

Lindsey, Tim and Butt, Simon, "State Power to Restrict Religious Freedom: An Overview of the Legal Framework", in Tim Lindsey and Helen Pausacker (Eds.), Religion, Law and Intolerance in Indonesia, New York: Routledge, 2016.

Nowak, Manfred \& Vospernik, Tanja, "Permissible Restrictions on Freedom of Religion or Belief', in Tore Lindholm, et. al (Eds.), Freedom of Religion or Belief: A Desk Book, Oslo: the Oslo Coalition on Freedom of Religion or Belief, 2004.

Peters, Rudolph and De Vries, Gert J.J, “Apostasy in Islam”, Die Welt des Islams, 17 (1-4), 1977.

Saeed, Abdullah and Saeed, Hassan, Freedom of Religion, Apostasy and Islam, New York: Routledge, 2004.

Talbi, Mohammed, Ummat al-W asat, Tunisia: Sarar li al-Nasyr, 1996. United Nations, International Covenant on Civil and Political Rights, Treaty Series, 1976. 
United Nations, Universal Declaration of Human Rights, illustrated edition, 2015.

25 | Afifur Rochman Sya'rani- Mediating Shari'a 